Jurnal Penelitian Hutan Tanaman Vol. 14 No. 2, Desember 2017, 139-153

ISSN: 1829-6327, E-ISSN: 2442-8930

Terakreditasi No: 677/AU3/P2MI-LIPI/07/2015

\title{
MODEL PENDUGAAN VOLUME POHON KARET SAAT PEREMAJAAN DI SEMBAWA, SUMATERA SELATAN
}

\author{
Estimation Model of Rubber Tree Volume at Replanting Time in Sembawa, South Sumatra
}

\author{
Sahuri \\ Balai Penelitian Sembawa, Pusat Penelitian Karet \\ Jalan Raya Palembang - P. Balai KM. 29, PO BOX 1127 Palembang, Indonesia \\ Email: sahuri_agr@ymail.com
}

Tanggal diterima: 26 Maret 2017; Tanggal direvisi: 24 Desember 2017;

Tanggal disetujui: 29 Desember 2017

\begin{abstract}
Estimation model of rubber (Hevea brasiliensis) tree volume compiled pursuant to one independent variable of stem girth. This study aimed to develop a model of mathematical equations to estimate the volume of rubber trees of clones GT 1, PR 255, PR 261, and the combined clones. The experiment was conducted at the Sembawa Research Station, South Sumatra. Sampling was purposive. The results showed that the volume of rubber tree clones of GT1, PR255, PR261 and mixed clones affected by stem girth at breast height and affected by clone.The model of PR255 clone volume, $V_{P R 255}=0.5827 G^{1.7182}\left(R^{2}=95.6 \%\right)$, klon GT1 $V_{G T 1}=0.5818 G^{1.0352}, \quad\left(R^{2}=97.8 \%\right)$, klon PR261 $V_{P R 261}=0.5651 G^{0.6471}\left(R^{2}=93.5 \%\right)$ and the mixed clones, $V=0.5806 G^{0.5696}\left(R^{2}=98.6 \%\right)$. At replanting time, rubber wood has a potential used for sawn timber, plywood, veneer and MDF raw materials. The biggest utilization of rubber wood is for MDF raw materials, because in $M D F$ processing all parts of the trees can be utilized.
\end{abstract}

Keywords: Clone, hevea brasiliensis, stem girth, and volume estimation

\begin{abstract}
Model penduga volume pohon karet (Hevea brasiliensis) disusun berdasarkan satu peubah bebas lilit batang. Penelitian ini bertujuan menyusun model persamaan matematis untuk menduga volume pohon karet jenis klon GT 1, PR 255, PR 261, dan klon gabungan. Penelitian dilaksanakan pada areal peremajan karet di Kebun Percobaan Balai Penelitian Sembawa, Sumatera Selatan. Pengambilan sampel pohon dilakukan secara purposive. Model penduga volume pohon karet klon GT1, PR255, PR261, dan klon gabungan dipengaruhi oleh lilit batang setinggi dada dan dipengaruhi oleh jenis klon. Model penduga volume klon PR255, $\mathrm{V}_{\mathrm{PR} 255}=0,5827 \mathrm{G}^{1,7182} \quad\left(\mathrm{R}^{2}=95,6 \%\right)$, klon $\mathrm{GT} 1 \quad \mathrm{~V}_{\mathrm{GT} 1}=0,5818 \mathrm{G}^{1,0352} \quad\left(\mathrm{R}^{2}=97,8 \%\right), \quad$ klon $\quad \mathrm{PR} 261$ $\mathrm{V}_{\mathrm{PR} 261}=0,5651 \mathrm{G}^{0,6471}\left(\mathrm{R}^{2}=93,5 \%\right)$, dan klon gabungan, $\mathrm{V}=0,5806 \mathrm{G}^{0,5696}\left(\mathrm{R}^{2}=98,6 \%\right)$. Pada saat peremajaan, kayu karet memiliki potensi untuk digunakan dalam industri kayu gergajian, kayu lapis, veneer, dan bahan baku MDF. Pemanfaatan kayu karet terbesar adalah untuk bahan baku MDF, karena pada pengolahan MDF semua bagian pohon dapat dimanfaatkan.
\end{abstract}

Kata kunci: Hevea brasiliensis, klon, lilit batang, dan pendugaan volume

\section{PENDAHULUAN}

Kebutuhan kayu untuk industri pengolahan kayu semakin meningkat, sedangkan sumberdaya hutan setiap tahun mengalami penurunan potensi (Kementerian Kehutanan Republik Indonesia, 2014). Hal ini menyebabkan pasokan kayu mengalami penurunan sehingga terjadi ketimpangan antara kebutuhan dan pasokan kayu (Sumadi, Azwar, \& Muara, 2006; Wedatama, Sutapa \& Irawati, 2010; Wijaya \& Dahlan, 2016). Oleh karena itu, diperlukan program pembangunan Hutan Tanaman Industri (HTI) yang dapat memasok kebutuhan kayu bagi industri. Menurut Nancy, Agustina, \& Syarifa (2013), HTI berbasis karet berpotensi 
sebagai salah satu pemasok atau penghasil kayu.

Kayu karet menjadi alternatif untuk menggantikan kayu hutan sebagai bahan baku industri seperti sawn timber, hard board, particle board, fibre board, dan furniture. Sejalan dengan program peremajaan karet rakyat di Indonesia, jumlah pabrik pengolahan kayu karet juga menjadi bertambah. Kondisi ini mendorong terbentuknya tataniaga kayu karet (Suheryanto \& Haryanto, 2009; Agustina, 2012; Nancy, Agustina, \& Syarifa, 2013; Setiawan, Sulaeman, \& Yoza, 2013).

Permasalahan yang muncul dari tataniaga ini adalah pada saat penaksiran volume pohon di lapangan, yaitu tingkat akurasi dalam mengestimasi volume pohon oleh pembeli selalu kurang tepat, sehingga merugikan pembeli (Isnaini, 2011). Oleh karena itu, diperlukan alat bantu yang dapat mempercepat kegiatan dan memperkecil kesalahan dalam pengukuran volume pohon di lapangan. Salah satu perangkat yang dapat menghitung potensi kayu adalah model penduga volume pohon.

Model penduga volume pohon dapat digunakan secara aktual untuk kebutuhan industri perkayuan baik dalam bentuk Hak Pengusahaan Hutan (HPH) maupun HTI yang berazaskan kelestarian hasil untuk menghasilkan kayu (Broto, 2008; Nuralexa, 2009; Harbagung \& Krisnawati, 2009; Isdwinanto, 2011; Abidin, 2011; Abdurachman, 2013).

Bentuk penampilan batang merupakan faktor dalam penentuan model untuk menduga volume pohon. Namun pertumbuhan pohon yang bervariasi akan menyebabkan bentuk dan ukuran yang berbeda. Oleh karena itu, pendugaan volume pohon yang bersifat umum harus dihindarkan karena akan menghasilkan dugaan yang kurang akurat antara angka dugaan dengan sebenarnya (Harbagung \& Krisnawati, 2009; Susila,
2012; Kuswandi, Sadono, Supriyatno, \& Marsono, 2015).

Penelitian ini bertujuan menyusun model persamaan matematis untuk menduga volume pohon karet jenis klon GT1, PR255, PR261, dan klon gabungan pada perkebunan karet, serta menyampaikan informasi mengenai potensi pemanfaatan kayu karet sebagai bahan baku industri berbasis kayu.

\section{METODOLOGI}

\section{A. Lokasi Penelitian}

Penelitian dilakukan pada areal peremajaan karet di Kebun Percobaan Balai Penelitian Sembawa, Kabupaten Banyuasin, Sumatera Selatan. Areal penelitian terletak pada Bujur Timur 104'32.382'BT dan Lintang Selatan $03^{\circ} 55.684^{\prime}$ LS serta ketinggian $10 \mathrm{~m}$ dari permukaan laut (dpl). Topografi areal sebagian besar relatif datar dengan kelerengan antara 0-10\%. Peta Kebun Riset Balai Penelitian Sembawa dan blok klon karet yang diamati disajikan pada Gambar 1.

Jenis tanah adalah ultisol dengan tekstur lempung liat berpasir. Hasil analisis tanah di lokasi penelitian menunjukkan bahwa kondisi $\mathrm{pH}$ sangat masam, C-organik rendah, N-total rendah, KTK dan kation $\mathrm{N}, \mathrm{P}, \mathrm{K}, \mathrm{Ca}, \mathrm{Mg}$ sangat rendah. Selain itu, tanah tersebut memiliki kejenuhan alumunium (Al) yang tinggi 50, 60\% (Tabel 1). Kondisi tanah yang demikian tergolong lahan bermasalah dan mempunyai tingkat kesuburan yang rendah (Wijaya, 2008). Namun tanaman karet termasuk tanaman adaptif pada kondisi lahan tersebut (Rosyid, Wijaya \& Boerhendhy, 2009; Siagian, Aidi-Daslin, \& Hadi, 2008).

Rata-rata curah hujan dilokasi penelitian adalah $2.000-3.000 \mathrm{~mm} /$ tahun dengan kelembaban udara sepanjang tahun $>80 \%$. Rata-rata suhu udara maksimum $32^{\circ} \mathrm{C}$ dan minimum $23^{\circ} \mathrm{C}$ (Khasanah, Wijaya, Vincent, June \& 
Noordwijk, 2008). Menurut Klasifikasi As-syakur (2009), lokasi penelitian termasuk dalam Tipe Iklim B-2, yaitu tipe iklim dengan jumlah bulan basah antara 7-9 bulan dan bulan kering antara 2-3 bulan (Gambar 2).

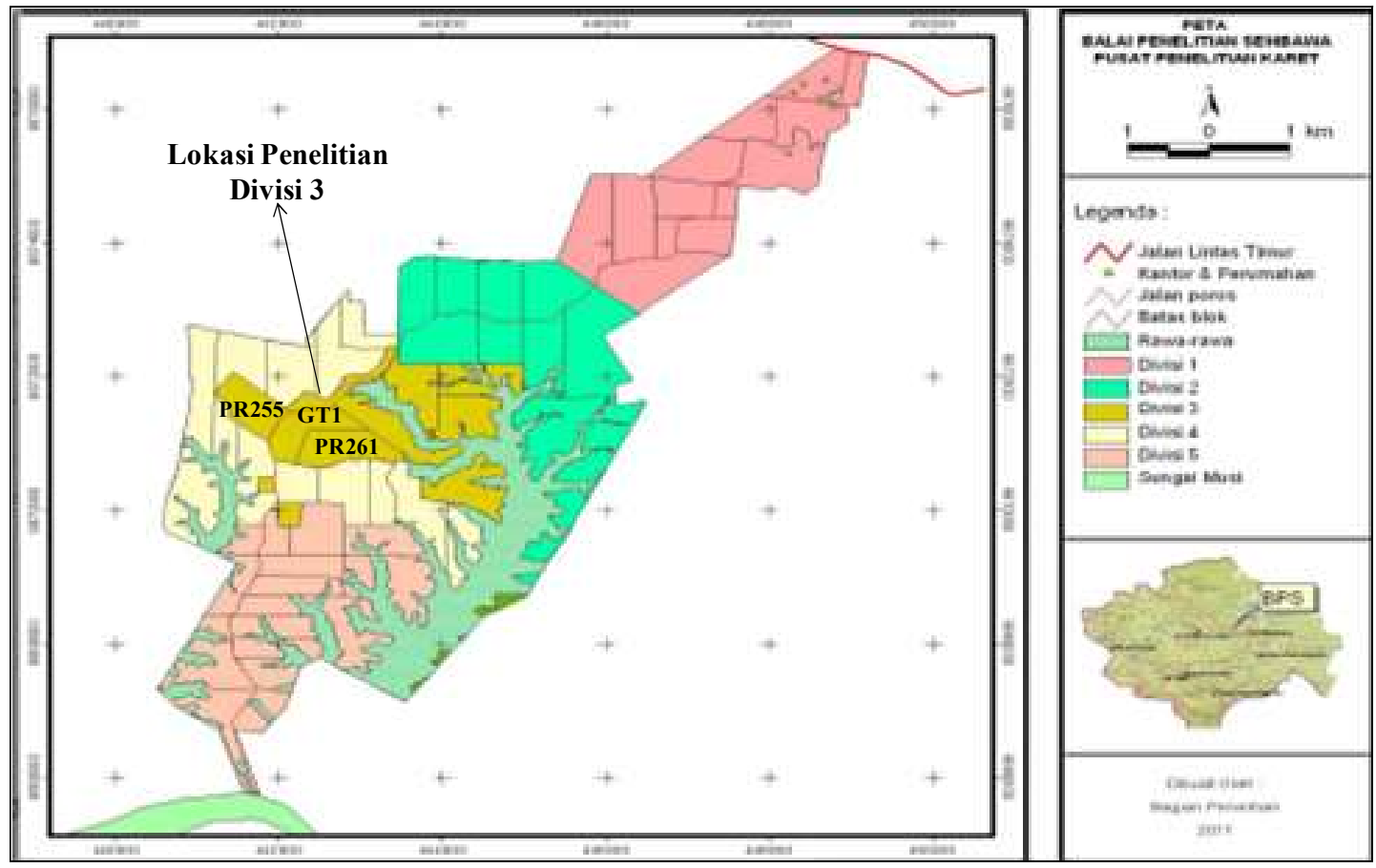

Sumber (source): Kebun Riset Balai Penelitian Sembawa (The Sembawa Research Station)

Gambar (Figure) 1. Peta Kebun Riset Balai Penelitian Sembawa (Map of Sembawa Research Station, South Sumatra)

Tabel (Table) 1. Data analisis tanah (Analysis data of soil)

\begin{tabular}{lc}
\hline \multicolumn{1}{c}{ Peubah analisis (Analysis variables) } & Kriteria (Criteria) \\
\hline $\mathrm{pH}$ & $4,37 \mathrm{sm}$ \\
$\mathrm{C}$-organik (\%) & $1,83 \mathrm{r}$ \\
$\mathrm{N}$-total (\%) & $0,13 \mathrm{r}$ \\
$\mathrm{P}_{2} \mathrm{O}_{5}($ Bray II) (ppm) & $4,77 \mathrm{sr}$ \\
$\mathrm{K}_{2} \mathrm{O}(\mathrm{Morgan})(\mathrm{me} / 100 \mathrm{gr})$ & $0,02 \mathrm{sr}$ \\
$\mathrm{Ca}(\mathrm{me} / 100 \mathrm{gr})$ & $0,11 \mathrm{sr}$ \\
$\mathrm{Mg}(\mathrm{me} / 100 \mathrm{gr})$ & $0,02 \mathrm{sr}$ \\
$\mathrm{KTK} /$ cation exchange capacity (me/100 gr) & $8,9 \mathrm{sr}$ \\
$\mathrm{Kejenuhan} \mathrm{Al} /$ Al saturation $(\%)$ & $50,60 \mathrm{st}$ \\
$\mathrm{Kelas}$ tekstur/texture class $(\%):$ & Lempung liat berpasir \\
& $($ clay sandy loam $)$ \\
- Pasir/sand & 46,67 \\
- Debu/silt & 25,83 \\
\hline
\end{tabular}

Keterangan (Remarks): $\mathrm{r}=\mathrm{rendah}($ low); $\mathrm{sr}=\mathrm{sangat}$ rendah (very low); $\mathrm{sd}=\mathrm{sedang}$ (medium); $\mathrm{t}=$ tinggi (high); $\mathrm{st}=$ sangat tinggi (very high); $\mathrm{m}=$ masam $($ acid $) ; \mathrm{sm}=$ sangat masam (very acid) 


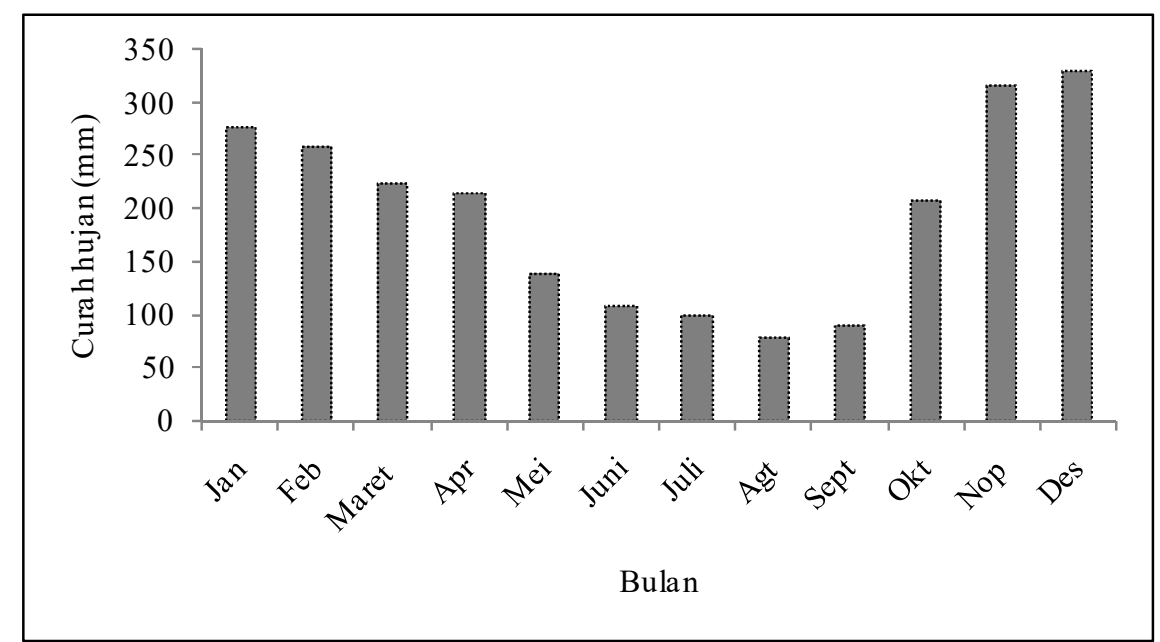

Gambar (Figure) 2. Rata-rata curah hujan bulanan musim tanam tahun 2006-2016 di Stasiun Balai Penelitian Sembawa (Monthly rainfall rate average in the 2006-2016 growing season in Sembawa Research Center Station)

\section{B. Metode \\ 1. Pengumpulan data}

Bahan penelitian penyusunan model penduga volume adalah tegakan tanaman karet yang diremajakan dari bahan tanam klon GT1, PR255, dan PR261 yang berumur 30 tahun dan sudah tidak produktif menghasilkan lateks. Data untuk menyusun model penduga volume pohon berasal dari pohon model yang dipilih secara purposive yang mewakili sebaran kelas lilit batang terkecil sampai dengan terbesar. Data lilit batang 60\% untuk penyusunan model dan $40 \%$ untuk validasi data. Kriteria pohon model yang dipilih adalah pertumbuhan batang dan tajuk normal serta sudah selesai masa sadap. Pada pohon model terpilih dilakukan pengukuran lilit batang utama setinggi dada (girth at breast height=gbh), tinggi bebas cabang, pengukuran seksi batang, dan cabang sampai lilit batang $\geq 20 \mathrm{~cm}$.

Pengukuran volume pohon diperoleh dengan cara: 1) volume kayu/pohon (log) $=$ jumlah potongan kayu $\mathrm{x}$ volume tiap potongan; 2) volume tiap potongan=luas penampang batang potongan $\mathrm{x}$ panjang potongan; dan 3) volume kayu karet setiap batang dihitung berdasarkan ukuran lilit batang batang utama dan cabang utama yang memenuhi kriteria $\geq 20 \mathrm{~cm}$ dengan memperhitungkan panjang batang utama dan cabangnya.

\section{Pengolahan dan analisis data a. Perhitungan volume pohon aktual}

Perhitungan volume pohon aktual dilakukan dengan menjumlahkan volume seksi-seksi batang dan cabang pohon. Perhitungan volume seksi batang dan cabang pohon dengan menggunakan persamaan Smalian (Sumadi, Nugroho \& Rahman, 2010) seperti berikut ini:

$$
\mathrm{Vs}=\frac{B p+B u}{2} \times \mathrm{L} \quad \mathrm{Va}=\sum_{i=1}^{n} V_{s}
$$

Keterangan: Vs = Volume seksi batang $\left(\mathrm{m}^{3}\right)$

$\mathrm{Va}=$ Volume aktual pohon $\left(\mathrm{M}^{3}\right)$

$\mathrm{Bp}=$ Luas bidang datar ujung seksi $\left(\mathrm{m}^{2}\right)$

$\mathrm{Bu}=$ Luas bidang datar ujung seksi $\left(\mathrm{m}^{2}\right)$

$\mathrm{L} \quad=$ Panjang seksi $(\mathrm{m})$ 


\section{b. Penyusunan persamaan regresi model penduga volume pohon}

Penyusunan model penduga volume pohon karet disusun berdasarkan satu peubah bebas lilit batang setinggi dada. Volume kayu yang dijadikan persamaan regresi adalah volume batang yang dimanfaatkan. Rumus model hubungan antara lilit batang dengan volume pohon karet adalah menggunakan hubungan korelasi, yaitu:

$$
\mathrm{Y}=\mathrm{f}\left(\mathrm{X}_{1}, \mathrm{X}_{2}, \mathrm{X}_{3}, \ldots . \mathrm{X}_{\mathrm{i}}\right)
$$

Keterangan: $\mathrm{Y}=$ Volume kayu $\left(\mathrm{m}^{3}\right)$

$$
\begin{aligned}
\mathrm{X}= & \text { Kondisi fisik tanaman } \\
& \text { karet } \\
\mathrm{f}= & \text { Fungsi korelasi }
\end{aligned}
$$

Rumus pendugaan volume melaui beberapa kondisi fisik tanaman adalah:

$$
\mathrm{V}=\mathrm{a} \mathrm{X}^{\mathrm{b}}
$$

$$
\text { Keterangan: } \begin{aligned}
\mathrm{V} & =\text { Volume kayu }\left(\mathrm{m}^{3}\right) \\
\mathrm{X} & =\text { Lilit batang }(\mathrm{cm}) \\
\mathrm{A} & =\text { Koefisien regresi } \\
\mathrm{B} & =\text { Penduga parameter }
\end{aligned}
$$

Dari persamaan di atas kemudian diubah menjadi persamaan:

$\log V=\log a+b \log G$

\section{c. Pengujian validasi model}

Model disusun berdasarkan satu peubah bebas lilit batang dan diuji validasi dengan akar rata-rata kuadrat simpangan (root means squared error $=\mathrm{RMSE}$ ), simpangan rata-rata (average deviation $=\mathrm{SR}$ ), simpangan agregatif (agregatif deviation $=\mathrm{SA}$ ), koefisien determinasi (determination coeficient $=$ $\mathrm{R}^{2}$ ) dan bias (e).

Nilai RMSE menyatakan tingkat kesalahan secara teknis dalam pengukuran. Semakin kecil nilai RMSE suatu model, maka keakuratan model tersebut semakin tinggi (Sumadi \& Siahaan, 2010) yang dinyatakan dengan rumus:

$$
\text { RSME }=\sqrt{\frac{\sum\left(\frac{V d-V a}{V a}\right)^{2}}{n}} \times 100 \%
$$

Nilai SR menyatakan besarnya perbedaan antara volume hasil dugaan dengan volume sebenarnya hasil pengukuran di lapangan secara rata-rata. Nilai SA menyatakan simpangan volume dugaan dengan volume sebenarnya secara agregat. Semakin kecil nilai simpangan rata-rata dan simpangan agregat suatu model, maka keakuratan model tersebut semakin tinggi. Kriteria kelayakan model digunakan apabila besar SA $<1 \%$ dan SR $<10 \%$. Nilai SA dan SR dihitung dengan rumus:

$$
\begin{aligned}
& \mathrm{SA}=\left[\frac{\sum V d-\sum V a}{\sum V d}\right] \times 100 \% \\
& \mathrm{SR}=\left[\frac{\left(\sum \frac{V d-V a}{V d}\right)}{n}\right] \times 100 \%
\end{aligned}
$$

Nilai bias (e) memberikan gambaran kesalahan sistematis yang dapat terjadi karena kesalahan teknis dan pengukuran, dengan rumusnya:

$$
\begin{gathered}
\text { Bias }=\sum\left(\frac{\left(\frac{V d-V a}{V c}\right)}{n}\right) \times 100 \% \\
\text { Keterangan: } \quad \begin{aligned}
V d & =\text { Volume dugaan } \\
V a & =\text { Volume aktual } \\
n & =\text { Jumlah data }
\end{aligned}
\end{gathered}
$$

\section{HASIL DAN PEMBAHASAN}

A. Hasil

1. Sebaran pohon model

Penelitian model penduga volume pohon karet menggunakan tanaman 
model klon GT 1, PR 255, dan PR 261 berumur 30 tahun, sudah tidak produktif untuk menghasilkan lateks. Tanaman sampel yang dijadikan model masingmasing klon berjumlah 200 pohon, sehingga total pohon yang diamati berjumlah 600 pohon. Populasi pohon pada saat peremajaan sekitar 300-350 pohon/ha dengan jarak tanam $7 \times 3 \mathrm{~m}$. Tanaman karet klon GT 1, PR 255, dan PR 261 memiliki lilit batang 50-160 cm. Sebaran jumlah tanaman karet yang diamati disajikan pada Tabel 2.

\section{Hubungan antara lilit batang dan volume kayu karet}

Diagram tebar digunakan untuk me-lihat tingkat signifikan antara lilit batang karet dengan volume kayu karet. Diagram tebar hubungan antara lilit batang dan volume kayu karet klon GT 1, PR 255, dan PR 261 disajikan pada Gambar 3. Gambar-gambar tersebut menunjukkan hubungan persamaan model beberapa jenis klon karet yang telah disesuaikan berdasarkan dari plot tebaran datanya. Pada gambar tersebut dapat dilihat bahwa pola penyebaran datanya tidak mengikuti suatu garis lurus melainkan mengikuti pola non-linier. Hal ini menunjukkan bahwa ketelitian yang ditunjukkan oleh lilit batang karet dalam menentukan pendugaan volume kayu sangat baik. Oleh karena itu, dalam melakukan penyusunan model penduga volume kayu terhadap lilit batang karet adalah mengikuti persamaan model nonlinier.

Pada Tabel 3 terlihat bahwa terdapat korelasi yang signifikan antara lilit batang dengan volume pohon karet klon GT1, PR255, PR261, dan klon gabungan. Hal ini menunjukkan bahwa keragaman volume pohon karet dipengaruhi oleh lilit batang setinggi dada.

\section{Model pendugaan volume kayu karet berdasrakan lilit batang}

Model penduga volume pohon karet dengan satu peubah bebas lilit batang pada klon GT1, PR255, dan PR261 disajikan pada Tabel 3.

Tabel (Table) 2. Sebaran lilit batang dan jumlah pohon karet berdasarkan jenis klon (The frequency distribution of stem girth and number of tree based clones)

\begin{tabular}{lcccc}
\hline \multirow{2}{*}{$\begin{array}{c}\text { Kelas lilit batang (Girth } \\
\text { classs) }(\mathrm{cm})\end{array}$} & \multicolumn{3}{c}{ Jumlah pohon (Number of tree) } & Total \\
\cline { 2 - 4 } & GT 1 & PR255 & PR261 & 7 \\
\hline $50-60$ & 2 & 3 & 2 & 29 \\
$60-70$ & 11 & 10 & 8 & 61 \\
$71-80$ & 19 & 22 & 20 & 138 \\
$81-90$ & 46 & 48 & 44 & 129 \\
$91-100$ & 45 & 38 & 46 & 118 \\
$101-110$ & 36 & 40 & 42 & 57 \\
$111-120$ & 19 & 18 & 20 & 28 \\
$121-130$ & 9 & 10 & 9 & 23 \\
$131-140$ & 9 & 8 & 6 & 7 \\
$141-150$ & 3 & 2 & 2 & 3 \\
$151-160$ & 1 & 1 & 1 & 600 \\
Jumlah (Sum) & 200 & 200 & 200 & \\
\end{tabular}



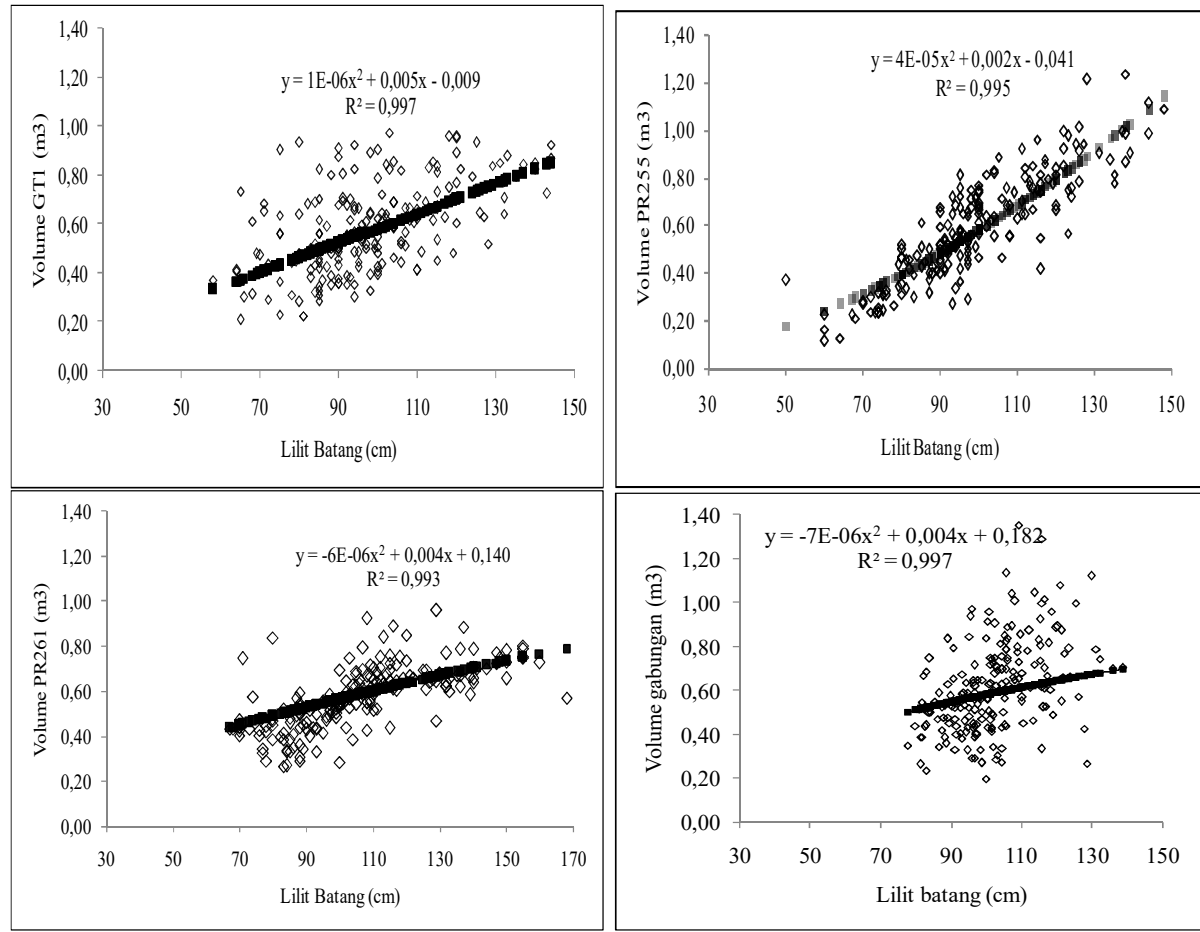

Gambar (Figure) 3. Hubungan lilit batang dengan volume kayu tanaman karet klon GT1, PR255, PR261 dan klon gabungan (Correlation of girth wih the volume of GT1, PR255, PR261, and mixed clones)

Tabel (Table) 3. Model pendugaan volume kayu karet dalam bentuk log dan sawn timber dengan bahan tanam klonal (Estimation model of the volume of rubber wood based on girth and clones)

\begin{tabular}{|c|c|c|c|c|c|c|}
\hline \multirow{2}{*}{$\begin{array}{c}\text { Jenis Klon } \\
\text { (Clones) }\end{array}$} & \multirow{2}{*}{$\begin{array}{l}\text { Persamaan } \\
\text { (Equation) }\end{array}$} & \multicolumn{5}{|c|}{ Statistik (Statistic) (\%) } \\
\hline & & $\mathrm{R}^{2}$ & SR & SA & RMSE & $\mathrm{e}$ \\
\hline GT1 & $0,5818 \mathrm{G}^{1,0352}$ & 97,8 & 3,82 & 0,04 & 8,81 & 3,94 \\
\hline PR255 & $0,5827 \mathrm{G}^{1,7182}$ & 95,6 & 3,19 & 0,03 & 6,75 & 3,09 \\
\hline PR261 & $0,5651 \mathrm{G}^{0,6471}$ & 93,5 & 2,17 & 0,02 & 9,84 & 6,60 \\
\hline $\begin{array}{l}\text { Klon gabungan } \\
\text { (Mixed clones) }\end{array}$ & $0,5806 \mathrm{G}^{0,5696}$ & 98,6 & 3,81 & 0,05 & 4,87 & 5,45 \\
\hline
\end{tabular}

Keterangan (Remark) : $\mathrm{R}^{2}=$ Koefisien determinasi (Determination coefficient), $\mathrm{SR}=$ Simpangan rata-rata (Average deviation), SA=Simpangan agregatif (Agregatif deviation), RMSE $=$ Root means squared error, $\mathrm{e}=$ bias

Pada Tabel 3 menunjukkan bahwa hasil statistik penggunaan peubah bebas lilit batang setinggi dada dalam menduga volume pohon karet klon GT1, PR255, dan PR261 cukup memenuhi syarat ketelitian suatu persamaan dalam menduga volume pohon berdasarkan nilai $\mathrm{R}^{2}$, SR, SA, RMSE, dan e. Menurut Harbagung \& Krisnawati (2009);
Kuswandi (2016); Susila (2012), suatu persamaan regresi untuk menduga volume pohon yang menggunakan satu peubah bebas lilit batang, nilai RMSE tidak lebih dari 25\%. Selanjutnya menurut Sumadi, Nugroho, \& Rahman (2010) dan Mukti (2013), kriteria kelayakan model penduga volume pohon dapat digunakan apabila nilai SA kurang 
dari $1 \%$ dan nilai SR kurang dari $10 \%$. Berdasarkan hasil analisis besarnya nilai SR dan SA pada model penduga volume pohon karet klon GT1, PR255, dan PR261 sudah menunjukkan tingkat kevalidan dengan nilai SA kurang dari $1 \%$ dan nilai SR kurang dari $10 \%$.

\section{B. Pembahasan}

Hubungan antara lilit batang dan volume kayu karet mengikuti pola nonlinier. Hal ini menunjukkan bahwa ketelitian yang ditunjukkan oleh lilit batang karet dalam menentukan pendugaan volume kayu sangat baik. Oleh karena itu, dalam melakukan penyusunan model penduga volume kayu terhadap lilit batang karet adalah mengikuti persamaan model non-linier. Hal ini sejalan dengan hasil penelitian Putranto (2011) dan Abidin (2011), yang menyatakan bahwa model non-linier merupakan penduga model yang lebih baik dibandingkan model linier bagi hubungan tinggi dan diameter dalam menentukan volume kayu. Kuswandi (2016), menambahkan bahwa metode pendugaan volume pohon yang memiliki akurasi lebih tinggi adalah dengan menggunakan tabel volume pohon yang dibuat berdasarkan persamaan regresi non linier. Sumadi \& Siahaan (2010) juga menyatakan bahwa persamaan regresi yang dibangun memberikan hubungan antara diameter dan tinggi pohon dengan volume pohon.

Hasil regresi hubungan antara lilit batang karet dan volume kayu karet memiliki keeratan korelasi yang signifikan. Hal ini karena tanaman karet pada areal perkebunan memiliki keadaan tempat tumbuh yang sama untuk setiap individu pohon. Korelasi antara lilit batang dengan volume pohon karet klon GT1, PR255, PR261, dan klon gabungan sangat erat dengan nilai korelasi masingmasing adalah $(\mathrm{r}=0,99, \mathrm{r}=0,98, \mathrm{r}=0,97$ dan $r=0,99)$. Hal ini menunjukkan bahwa keragaman volume pohon karet dipengaruhi oleh lilit batang setinggi dada. Oleh karena itu, hasil ini sama dengan beberapa penelitian yang dilakukan, dimana terdapat hubungan korelasi yang erat antara diameter dengan volume pohon dengan $\mathrm{R}^{2}$ lebih besar dari 60\% (Qirom \& Supriyadi, 2012; Qirom \& Supriyadi, 2013).

Model penduga volume pohon karet klon GT1, PR255, PR261, dan klon gabungan dipengaruhi oleh lilit batang setinggi dada dan dipengaruhi oleh jenis klon. Model penduga volume klon PR255, $\quad \mathrm{V}_{\mathrm{PR} 255}=0,5827 \mathrm{G}^{1,7182}, \quad \mathrm{R}^{2}$ $(95,6 \%)$, RMSE $(6,75 \%)$, SR $(3,19 \%)$, SA $(0,03 \%)$, dan e $(3,09 \%)$; klon GT1, $\mathrm{V}_{\mathrm{GT1}}=0,5818 \mathrm{G}^{1,0352}, \mathrm{R}^{2}(97,8 \%)$, RMSE $(8,81 \%)$, SR $(3,82 \%)$, SA $(0,04 \%)$, dan e $(3,94 \%)$; klon PR261, $\mathrm{V}_{\text {PR } 261}=0,5651 \mathrm{G}^{0,6471}, \mathrm{R}^{2}(93,5 \%), \mathrm{RMSE}$ $(9,84 \%)$, SR $(2,17 \%)$, SA $(0,02 \%)$, dan e $(6,60 \%)$, dan klon gabungan, $\mathrm{V}=0,5806 \mathrm{G}^{0,5696}, \quad \mathrm{R}^{2} \quad(98,6 \%), \quad \mathrm{RMSE}$ $(4,78 \%)$, SR $(3,81 \%)$, SA $(0,05 \%)$, dan e $(5,45 \%)$.

Klon GT1, PR255, dan PR261 merupakan klon lateks-kayu dalam rekomendasi klon anjuran karet periode 1999-2001. Klon PR 261 direkomendasikan untuk penanaman komersial sejak tahun 1974, sedangkan PR 255 dan PR 300 direkomendasikan sejak tahun 1983 (Woelan \& Pasaribu, 2009).

Pada rekomendasi klon anjuran komersial periode 2010-2014, klon tersebut tidak masuk dalam klon anjuran komersial, tetapi klon tersebut masih dapat digunakan (Lasminingsih, 2011). Klon GT1, PR255, dan PR261 memiliki pertumbuhan sedang hingga baik pada tanaman belum menghasilkan (TBM) dan tanaman menghasilkan (TM). Laju pertumbuhan lilit batang $<11 \mathrm{~cm}$ per tahun pada masa TBM dan $<4 \mathrm{~cm}$ per tahun pada masa tanaman menghasilkan (TM). Masa tebang tanaman karet adalah umur 25-30 tahun (Siagian, Aidi-Daslin 
\& Hadi, 2008; Woelan \& Pasaribu, 2009; Lasminingsih, 2011).

Saat ini, tanaman karet dinilai cukup potensial sebagai komoditas untuk pembangunan HTI. Terbatasnya bahan baku kayu bulat dan semakin meningkatnya kebutuhan kayu mendorong pengusaha kayu mencari jenis kayu lain untuk substitusi (Siagian, Supriadi, \& Siregar, 2008; Woelan, Siagian, Sayurandi, \& Pasaribu, 2012; Towaha \& Daras, 2013). Sifat alami kayu karet dapat digunakan sebagai bahan substitusi dari kayu ramin, akasia, mahoni, sengon, dan pinus untuk bahan baku kayu olahan (Suheryanto \& Haryanto, 2009; Arsad, 2009; Suheryanto, 2010), karena sifat-sifat kayu karet yang tidak jauh berbeda dengan sifat kayu tanaman HTI lainnya (Tabel 4). Pada Tabel 4 terlihat bahwa kelas kuat kayu karet setara dengan kayu akasia, ramin, dan mahoni, sedangkan untuk kelas awet kayu setara dengan kayu ramin dan sengon.
Beberapa sifat dasar yang berkaitan dengan kualitas kayu yang digunakan untuk berbagai produk industri antara lain sifat fisis, mekanis, dan kimia. Berdasarkan sifat fisis dan mekanis kayu karet tergolong kelas kuat II sedangkan untuk analisis terhadap komponen kimia dan dimensi serat, kayu karet termasuk dalam kelas kualitas serat II (Suheryanto \& Haryanto, 2009; Arsad, 2009; Putri, Herawati, \& Batubara, 2013). Secara umum, berat jenis kayu karet $0,61 \mathrm{~g} / \mathrm{cm}^{3}$ dengan persentase penyusutan 1,73\%. Pada Tabel 5 terlihat bahwa nilai MOR (modulus of rupture) dan keteguhan tekan klon GT 1 lebih besar dibandingkan dengan klon PR 255 dan PR 261. Hal ini menunjukkan bahwa sesuai dengan klasifikasi kekuatan kayu dalam $\mathrm{P} 3 \mathrm{HH}$ [Pusat Penelitian dan Pengembangan Hasil Hutan]. 2008), bahwa klon GT 1 termasuk dalam kategori kayu kelas kuat II, sedangkan kayu klon PR 255 dan PR 261 merupakan kelas awet III.

Tabel (Table) 4. Perbandingan sifat kayu HTI dengan kayu karet (Comparison of wood properties between rubber tree and other tree plantation species)

\begin{tabular}{lccc}
\hline \multirow{2}{*}{ Jenis kayu (Species) } & \multirow{2}{*}{ Berat jenis (Wood density) } & \multicolumn{2}{c}{ Kelas (Class) } \\
\cline { 3 - 4 } & & Kuat (Strength) & Awet (Durability) \\
\hline Hevea brasiliensis (Karet) & 0,61 & II-III & V \\
Acacia mangium (Akasia) & 0,61 & II-III & III \\
Gonystylus bancanus (Ramin) & 0,63 & II-III & V \\
Swietenia macrophylla (Mahoni) & 0,64 & II-III & III \\
Pinus merkusii (Pinus) & 0,55 & III & IV \\
Albizzia falcata (Sengon) & 0,40 & V & IV/V \\
\hline
\end{tabular}

Sumber (Source): Suheryanto \& Haryanto (2009)

Tabel (Table) 5. Sifat fisik dan mekanik beberapa klon kayu karet (Physical and mechanical properties of several rubber clones)

\begin{tabular}{lcccccc}
\hline Klon (Clone) & $\begin{array}{c}\text { Kadar air } \\
\text { (Measure } \\
\text { content) }(\%)\end{array}$ & $\begin{array}{c}\text { Berat } \\
\text { jenis } \\
\text { (Wood } \\
\text { density) } \\
(\text { Bo/Vo) }\end{array}$ & $\begin{array}{c}\text { Penyusutan } \\
\text { Shrinkage) } \\
(\%)\end{array}$ & $\begin{array}{c}\text { MOR } \\
\left(\mathrm{kg} / \mathrm{cm}^{2}\right)\end{array}$ & $\begin{array}{c}\text { keteguhan } \\
\text { tekan } \\
\text { (Pressure } \\
\text { toughness) } \\
\left(\mathrm{kg} / \mathrm{cm}^{2}\right)\end{array}$ & MOR/BJ \\
\hline GT 1 & 10,61 & 0,65 & 1,27 & 730,91 & 452,28 & 1082,94 \\
PR 255 & 10,91 & 0,60 & 2,01 & 631,10 & 362,47 & 1051,83 \\
PR 261 & 10,90 & 0,59 & 1,92 & 535,68 & 352,46 & 907,93 \\
Rata-rata (Average) & 10,81 & 0,61 & 1,73 & 632,56 & 389,07 & 1014,23 \\
\hline Kerangan (terars)
\end{tabular}

Keterangan (remarks): MOR = Modulus patah (Modulus of rupture); BJ = Berat jenis ( Wood density) 
Pada Tabel 6 secara umum karakteristik kimia dan dimensi serat kayu karet termasuk dalam kelas mutu II (Boerhendhy \& Agustina, 2006; Putri, Herawati, \& Batubara, 2013). Namun pada kriteria nilai bilangan Runkel dan koefisien kekakuan, klon GT 1, dan PR 255 masuk dalam kelas mutu III. Hal ini karena menurut Setianto (2013), kayu karet tergolong kayu yang agak lunak hingga agak keras dengan densitas antara $435-625 \mathrm{~kg} / \mathrm{m}^{3}$ dan berat jenis rata-rata $0,61 \mathrm{~g} / \mathrm{cm}^{3}$ dengan kisaran 0,55-0,70 $\mathrm{g} / \mathrm{cm}^{3}$. Siregar (2012), menambahkan bahwa kayu karet memenuhi kriteria dalam persyaratan untuk bahan pulp dan kertas dengan kualitas pulp yang baik. Hal ini karena panjang serat rata-rata $1138,6 \mu \mathrm{m}$, diameter serat rata-rata 26,5 $\mu \mathrm{m}$, diameter lumen rata-rata $19,7 \mu \mathrm{m}$ dan tebal dinding serat rata-rata 3,4 $\mu \mathrm{m}$.

Peremajaan pada perkebunan karet menghasilkan kayu potensial yang dapat dimanfaatkan sebagai bahan baku industri berbasis kayu (Siagian, Supriadi \& Anwar, 2010; Agustina, 2012; Agustina et al., 2013). Hasil penjualan kayu karet dapat dijadikan modal untuk penanaman karet berikutnya (Siagian, Supriadi \& Anwar, 2010; Agustina, Syarifa \& Nancy, 2013). Namun, hasil kayu karet yang sebagian besar didominasi perkebunan karet rakyat sehingga relatif lebih rendah dibandingkan dengan hasil kayu pada perkebunan besar (Siagian, Supriadi \& Anwar, 2010). Hasil kajian Indonesian Sawmill and Woodworking Association (ISWA) menunjukkan bahwa seluruh tanaman karet memiliki manfaat, yaitu tunggul dan cabang akar (15\%) untuk arang dan papan partikel, batang bekas sadapan (15-20\%) untuk papan gypsum dan paruquet (flooring), batang bekas sadapan (20-25\%) untuk furniture, kayu lapis, dan kayu rekonstruksi dan diatas batang (10-15\%) untuk kayu olahan. Cabang utama dan kedua bisa meng-hasilkan produk kerajianan tangan, mainan, serta papan serat, sedangkan ranting dan daun bisa untuk kompos dan arang (Kaban, 2009; Amypalupy, 2010).

Kayu pada batang utama yang bebas cabang akan digunakan untuk pembuatan kayu gergajian, sedangkan kayu percabangan (kanopi) dapat digunakan untuk pembuatan Medium Density Fibreboard (MDF), chipboard, serta pulp (Siagian, Supriadi \& Anwar, 2010). Potensi kayu karet dari hasil volume yang dapat dimanfaatkan untuk beberapa kayu olahan industri primer hasil hutan kayu (IPHHK) disajikan pada Tabel 7. Berdasarkan Peraturan Dirjen Bina Produksi Kehutanan No. P.13/VI-BPPHH/2009 rendemen kayu bulat dari tanaman karet yang digunakan untuk industri kayu gergajian sebesar 32-53\%, untuk industri MDF $75-90 \%$, sedangkan untuk veneer 56-59\%. (Siagian, Supriadi \& Anwar, 2010). Kayu karet dari klon GT1, PR255, dan PR261 memiliki potensi besar untuk industri kayu gergajian, kayu lapis, maupun veneer. Volume kayu terbesar yaitu untuk penggunaan MDF, hal ini dikarenakan pada pengolahan MDF semua bagian pohon dapat dimanfaatkan (Agustina, Syarifa \& Nancy, 2013). 
Tabel (Table) 6. Sifat kimia dan dimensi serat beberapa klon kayu karet (Chemical properties and fiber dimension of several rubber clones)

\begin{tabular}{|c|c|c|c|}
\hline Karakteristik (Characteristics) $\left.{ }^{*}\right)$ & GT 1 & PR 255 & PR 261 \\
\hline \multicolumn{4}{|l|}{ Sifat kimia ( Characteristic of chemical) $(\%)$} \\
\hline Kadar holoselulosa ( Holocelulose content) & 67,44 & 67,89 & 67,27 \\
\hline Kadar lignin (Lignin content) & 20,99 & 20,87 & 20,5 \\
\hline Kadar pentosan ( Pentosan content) & 17,9 & 17,9 & 17,3 \\
\hline Kelarutan dalam air dingin (Solubility in cold water) & 4,14 & 4,91 & 5,01 \\
\hline Kelarutan dalam air panas ( Solubility in hot water) & 7,86 & 8,58 & 9,01 \\
\hline Kelarutan dalam NAOH $1 \%$ ( Solubility in $\mathrm{NaOH}$ of $1 \%$ ) & 14,45 & 16,2 & 12,8 \\
\hline Kelarutan dalam alkohol benzena (Solubility in benzene alcohol) (1:2) & 4,25 & 4,71 & 4,71 \\
\hline Kadar abu (Ash content) & 0,72 & 0,768 & 0,742 \\
\hline Kadar silika ( Silica content) & 0,151 & 0,229 & 0,12 \\
\hline \multicolumn{4}{|l|}{ Dimensi serat (The fiber dimension) } \\
\hline Panjang serat (Long fiber) $(\mu \mathrm{m})$ & 1731 & 1579 & 1571 \\
\hline Diameter serat (Fiber diameter $)(\mu \mathrm{m})$ & 25,02 & 23,58 & 23,25 \\
\hline Diameter lumen (Lumen diameter $)(\mu \mathrm{m})$ & 15,66 & 15,79 & 16,38 \\
\hline Tebal dinding (Thick wall) $(\mu \mathrm{m})$ & 4,68 & 3,95 & 3,53 \\
\hline Daya tenun (Weaving power ) & 69,18 & 66,96 & 67,57 \\
\hline Fleksibilitas rasio (Flexibility ratio) & 0,68 & 0,67 & 0,7 \\
\hline Koefisien kekakuan (Stiffness coefficient) & 0,18 & 0,16 & 0,15 \\
\hline
\end{tabular}

Keterangan (Remarks): ${ }^{*}$ Berat kering oven (Dry weight of oven)

Tabel (Table) 7. Potensi pemanfaatan kayu (The potential of rubber wood utilization)

\begin{tabular}{ccccc}
\hline \multirow{2}{*}{ Klon (Clones) $)$} & $\begin{array}{c}\text { Volume kayu } \\
\text { (Wood volume } \\
\end{array}$ & \multicolumn{3}{c}{ Pemanfaatan kayu (Rubber utilization) $\left(\mathrm{m}^{3} / \mathrm{ha}\right)$} \\
\cline { 3 - 5 } & 173 & Kayu gergajian (Sawn timber $)$ & MDF & Veneer \\
\hline GT 1 & 191 & 74 & 143 & 102 \\
PR 255 & 191 & 81 & 158 & 113 \\
PR 261 & 81 & 158 & 113 \\
\hline
\end{tabular}

Sumber (Source): Siagian, Supriadi \& Anwar, (2010)

Penjualan kayu karet dapat memberikan keuntungan sehingga dapat dimanfaatkan untuk modal dalam peremajaan tanaman karet (Siagian, Supriadi \& Anwar, 2010; Agustina, 2012; Agustina et al., 2013). Keuntungan terbesar yang diterima oleh supplier adalah pada penjualan kayu untuk bahan MDF yaitu sebesar RP 750 ribu sampai Rp 2,9 juta/truk, sedangkan untuk keuntungan kayu gergajian dan veneer masing-masing $\mathrm{Rp} 461,5$ ribu/truk dan $\mathrm{Rp} 450$ ribu sampai $\mathrm{Rp} 930$ ribu/truk. Muatan kayu untuk bahan baku MDF per truk sebanyak $7 \mathrm{~m}^{3}$, sedangkan untuk bahan baku kayu gergajian dan veneer hanya berkisar 4-5 $\mathrm{m}^{3}$ (Agustina, Syarifa
\& Nancy, 2013). Namun dari nilai tersebut, petani hanya mendapatkan Rp 2 juta sampai Rp 14 juta per hektar dengan jumlah tegakan 300-500 pohon/ha pada saat peremajaan (Siagian, Supriadi \& Anwar, 2010; Agustina, 2012; Agustina et al., 2013).

\section{KESIMPULAN DAN SARAN}

\section{A. Kesimpulan}

Model penduga volume pohon karet klon GT1, PR255, PR261, dan klon gabungan dipengaruhi oleh lilit batang setinggi dada dan dipengaruhi oleh jenis klon. Model penduga volume klon 
PR255, $\quad \mathrm{V}_{\mathrm{PR} 255}=0,5827 \mathrm{G}^{1,7182} \quad\left(\mathrm{R}^{2}=\right.$ 95,6\%), klon GT1 $\mathrm{V}_{\mathrm{GT} 1}=0,5818 \mathrm{G}^{1,0352}$ $\left(\mathrm{R}^{2}=97,8 \%\right)$, klon PR261 $\mathrm{V}_{\mathrm{PR} 261}=$ $0,5651 \mathrm{G}^{0,6471} \quad\left(\mathrm{R}^{2}=93,5 \%\right)$, dan klon gabungan, $\mathrm{V}=0,5806 \mathrm{G}^{0,5696}\left(\mathrm{R}^{2}=98,6 \%\right)$. Pada saat peremajaan, kayu karet memiliki potensi untuk industri kayu gergajian, kayu lapis, veneer dan bahan baku MDF. Pemanfaatan kayu karet terbesar adalah untuk bahan baku MDF, karena pada pengolahan MDF semua bagian pohon dapat dimanfaatkan.

\section{B. Saran}

Dalam pendugaan volume pohon karet harus memperhatikan keakuratan dan ketelitian rumus yang digunakan serta memperhatikan kondisi atau susunan tanaman karet di lapangan.

\section{UCAPAN TERIMA KASIH}

Ucapan terimakasih kepada Ir. M. Jahidin Rosyid, MS sebagai peneliti utama yang telah memberikan masukan dan saran dalam penulisan makalah ini. Ucapan terima kasih juga disampaikan kepada Oktalisa Yuna, Amd sebagai teknisi yang telah membantu terlaksananya penelitian ini.

\section{DAFTAR PUSTAKA}

Abdurachman. (2013). Model pendugaan volume pohon Dipterocarpus confertus V. Slooten di wahau kutai timur, kalimantan timur. Jurnal Penelitian Dipterokarpa, 7(1), 29-34.

Abidin, Z. (2011). Penyusunan persamaan penduga volume pohon kelompok jenis Dipterocarpaceae di PT Timberdana Kalimantan Timur [Skripsi]. Institut Pertanian Bogor, Indonesia.

Amypalupy, K. (2010). 455 Info Padu Padan Teknologi Merajut Asa Ketangguhan Agribisnis Karet. Balai
Penelitian Sembawa-Pusat Penelitian Karet.

Agustina, D.S. (2012). Pemanfaatan kayu karet di beberapa negara produsen Karet alam dunia. Warta Perkaretan, 31(2), 85 - 94.

Agustina, D.S., Syarifa, L.F., \& Nancy, C. (2013). Kajian kelembagaan dan kemitraan pemasaran kayu karet di Provinsi Sumatera Selatan. Jurnal Penelitian Karet, 31(1), 54-67.

Arsad, E. 2009. Kayu karet sebagai substitusi kayu hutan alam untuk industri, Jurnal Riset Industri Hasil Hutan, 1(1), 31 - 37.

As-syakur, A.R. (2009). Evaluasi Zona Agroklimat Dari Klasifikasi Schimidt-Ferguson Menggunakan Aplikasi Sistem Informasi Geografi (SIG). Jurnal Pijar MIPA, 3(1), 1722.

Broto, H. (2008). Model penduga volume pohon sengon pada tegakan hutan rakyat.[Skripsi]. Institut Pertanian Bogor.

Harbagung, \& Krisnawati, H. (2009). Model taper batang tanaman Khaya anthoteca C.DC. di hutan penelitian Pasirhantap, Sukabumi, Jawa Barat. Jurnal Penelitian Hutan dan Konservasi Alam, 6(1), 13-24.

Isdwinanto, F.M. (2011). Penyusunan model penduga volume pohon jenis keruing (Dipterocarpus Sp.) Di IUPHHK-HA PT. Salaki Summa Sejahtera, Sumatera Barat.]Skripsi]. Institut Pertanian Bogor.

Isnaini, H.N. (2011). Pengelompokan jenis dalam penyusunan tabel volume lokal di IUPHHK-HA PT. Mamberamo Alas Mandiri, Provinsi Papua. Skripsi. Fakultas Kehutanan. IPB. Bogor.

Kaban, M.S. (2009). Kebijakan pengembangan kayu karet melalui 
hutan tanaman rakyat (pp. 2-5) Pros. Lok.Nas. Pemuliaan Tanaman Karet 2009, Batam, 4-6 Agustus 2009. Pusat Penelitian Karet.

Kementerian Kehutanan Republik Indonesia. (2014). Statistik Kehutanan Indonesia 2014. Jakarta.

Khasanah, N., Wijaya, T., Vincent, G., June, T., \& Van Noordwijk, M. (2008). Status air dan lingkungan radiasi dalam sistem karet monokultur dan campuran dengan akasia (Acacia mangium). Jurnal Penelitian Karet, 26(1), 31-48.

Kuswandi, R., Sadono, R., Supriyatno, N., \& Marsono, D. (2015). Keanekaragaman struktur tegakan hutan alam bekas tebangan berdasarkan biogeografi di Papua. Jurnal Manusia dan Lingkungan, 22(2), 151-159.

Kuswandi, R. (2016). Model penduga volume pohon kelompok jenis komersial pada wilayah Kabupaten Sarmi, Papua. Jurnal WASIAN, 3(2), 91-96

Lasminingsih, M. (2011). Rekomendasi klon karet 2010-2014. [Leaflet]. Balai Penelitian Sembawa, Pusat Penelitian Karet.

Mukti, G.A. (2013). Penyusunan model pendugaan volume kayu lokal sortimen jati (Tectona grandis l. f.) di KPH Semarang Perum Perhutani Unit I Jawa Tengah. [Skripsi]. Universitas Gadjah Mada, Indonesia.

Nancy, C., Agustina, D.S., \& Syarifa, L.F. (2013). Potensi kayu hasil peremajaan karet rakyat untuk memasok industri kayu karet studi kasusdi Provinsi Sumatera Selatan. Jurnal Penelitian Karet, 31(1), 6878.

Nuralexa, F.D. (2009). Karakteristik sifat anatomi dan fisis small diameter log sengon (Paraserianthes falcataria (L.) Nielsen) dan gmelina (Gmelina arborea Roxb.).[Skripsi]. Institut Pertanian Bogor.

P3HH [Pusat Penelitian dan Pengembangan Hasil Hutan]. 2008. Petunjuk Praktis Sifat-Sifat Dasar Jenis Kayu Indonesia: A handbook of selected Indonesian wood species. Indonesian Sawmill and Woodworking Association (ISWA).

Putranto, B. (2011). Penduga Model Hubungan Tinggi dan Diameter Pohon Jenis Jambu-Jambu (Kjellbergiodendron sp.) Pada Hutan Alam Di Kab Mamuju Sulawesi Barat. Prosiding Seminar Nasional Masyarakat Peneliti Kayu Indonesia (Mapeki) XIV.

Putri, N., Herawati, E., \& Batubara, R. (2013). Pengawetan Kayu Karet (Hevea braziliensis MUELL Arg) menggunakan Asam Borat (H3BO3) dengan metode pengawetan rendaman panas dingin. Peronema Forestry Science,2(1), 1-8.

Qirom, M.A., \& Supriyadi. (2012). Penyusunan model penduga volume pohon jenis jelutung rawa (Dyera Polyphylla (Miq) V. Steenis). Jurnal Penelitian Hutan Tanaman, 9(3), 141-153.

Qirom, M.A., \& Supriyadi. (2013). Model penduga volume pohon nyawai (Ficus variegata Blume) di Kalimantan Timur. Jurnal Penelitian Hutan Tanaman, 10(4), 173-184.

Rosyid, M.J., Wijaya, T., \& Boerhendhy, I. (2009). Pengujian adptabilitas beberapa klon karet di daerah pasang surut dengan tipe luapan D di Sumatera Selatan. (pp 252-261). Prosisding Lokakarya Nasional Pemuliaan Tanaman Karet 2009, Batam, 4-6 Agustus 2009. hlm. 252261. 
Setianto, F. (2013). Analisis distorsi volume dan analisis kekuatan sambungan bahan kayu karet dan bengkirai. [Tesis]. Fakultas Teknik. Universitas Diponegoro, Semarang.

Setiawan, F., Sulaeman, R., \& Yoza, D. (2013). Karakteristik kayu lapis dari bahan baku kayu karet (Hevea braziliensis Muell. Arg) berdasarkan umur pohon.[Skripsi]. Jurusan Kehutanan, Universitas Riau.

Siagian, N., Aidi-Daslin, \& Hadi, H. (2008). Potensi produksi klon unggul karet dan upaya pencapaiannya (pp. 95-116). Pros. Lok.Nas. Agribisnis Karet 2008, Yogyakarta, 20-21 Agustus 2008. Pusat Penelitian Karet. hlm 95-116.

Siagian, N., Supriadi, M., \& Siregar, T.H.S. (2008). Potensi ketersediaan kayu karet untuk bahan baku industri berbasis kayu dan rendemen kayu karet gergajian. Jurnal Penelitian Karet, 26(2), 176-203.

Siagian, N., Supriadi, M., \& Anwar, C. (2010). Potensi produksi kayu karet tua di tingkat petani dan perkebunan serta kendala dalam pemanfaatan. Jurnal Penelitian Karet, 28(1), 2643.

Siregar, N. (2012). Peluang benuang bini (Octomeles sumatrana Miq) sebagai bahan baku pulp. Mitra Hutan Tanaman, 7(1): 23 - 30 .

Suheyanto, D. (2010). Pengaruh konsentrasi cupri sulfat terhadap keawetan kayu karet. Seminar Rekayasa Kimia Dan Proses 2010. Jurusan Teknik Kimia Fakultas Teknik Universitas Diponegoro Semarang. hlm. 61-69. http://eprints.undip.ac.id/28056/1/E06.pdf.

Sumadi, A., \& Siahaan, H. (2010). Model penduga volume pohon kayu bawang di Provinsi Bengkulu (Disoxylum molliscimum BurmF.)." Jurnal Penelitian Hutan Tanaman, 7(5), 227-31.

Sumadi, A., Nugroho, A.W., \& Rahman, T. (2010). Model penduga volume pohon pulai gading di Kabupaten Musi Rawas Sumatera Selatan. Jurnal Penelitian Hutan Tanaman, 7(2), 107-112.

Suheryanto, D., \& Haryanto, T. (2009). Pemanfaatan kayu karet untuk furniture (pp. 1-8). Prosiding Seminar Nasional Penelitian, Pendidikan dan Penerapan MIPA, Yogyakarta, 16 Mei 2009. Fakultas MIPA, Universitas Negeri Yogyakarta. hlm. 1-8.

Susila, I.W.W. (2012). Model dugaan volume dan riap tegakan jati (Tectona Grandis L.F) di Nusa Penida, Klungkung Bali. Jurnal Penelitian Hutan Tanaman, 9(3), 165-178.

Towaha, J. \& Daras, U. (2013). Peluang pemanfaatan kayu karet (Hevea brasiliensis) sebagai kayu industri. Warta Penelitian dan Pengembangan Tanaman Industri, 19(2), 26-31.

Wijaya, T. (2008). Kesesuaian tanah dan iklim untuk tanaman karet. Warta Perkaretan, 27 (2): 34-44.

Wijaya, D.H., \& Dahlan, D. (2016). Karakterisasi fasa dan kapasitansi elektroda kayu karet yang dielektrodeposisi menggunakan CuSO4 untuk aplikasi elektroda superkapasitor. Jurnal Fisika Unand, 5(1), 78-84.

Wedatama, S., Sutapa , J.P.G., \& Irawati, D. (2010). Peningkatan kualitas kayu karet dengan compregnasi menggunakan urea formaldehida (pp. 113-116). Prosiding Seminar Nasional Masyarakat Peneliti Kayu Indonesia (MAPEKI) XVI. 
Biodegradasi Dan Peningkatan Kualitas Kayu, Bali 10-11 Nopember 2010. Bogor: Masyarakat Peneliti Kayu Indonesia. hlm. 113-116.

Woelan, S., \& Pasaribu, S.A. (2009). Pembentukan klon karet unggul baru melalui metode konvensional selama dekade ke-2 (1996-2005) (pp 224235). Prosisding Lokakarya Nasional Pemuliaan Tanaman Karet 2009,
Batam, 4-6 Agustus 2009. hlm. 224235.

Woelan, S., Siagian, N., Sayurandi, \& Pasaribu, S.A. (2012). Potensi kayu karet hasil peremajaan di tingkat perusahaan perkebunan. Warta Perkaretan, 31(2), 75-84. 